\title{
Efek Konsentrasi Sublethal Fenol Terhadap Total Haemocyte Count (THC) dan Histologi Insang Kepiting Bakau (Scylla serata)
}

\author{
Alfi Hermawati Waskita Sari ${ }^{1 *}$, Yenny Risjani ${ }^{1}$, Agung Pramana Warih Marhendra ${ }^{2}$ \\ ${ }^{1}$ Fakultas Perikanan dan Ilmu Kelautan, Universitas Brawijaya \\ 2Jurusan Biologi, Fakultas Matematika dan Ilmu pengetahuan Alam, Universitas Brawijaya
}

\begin{abstract}
Abstrak
Hadirnya fenol yang melebihi batas ambang ke dalam ekosistem perairan dapat menjadi stresor kimia bagi organisme akuatik, termasuk juga bagi ekosistem muara oleh karena muara (estuaria) merupakan daerah pertemuan antara air tawar dari perairan sungai dan air laut sehingga berpotensi mengandung bahan kimia antropogenik. Kepiting bakau (Scylla spp.) memiliki siklus hidup yang sebagian besar berada pada ekosistem mangrove dan umum digunakan dalam studi ekotoksisitas. Total Haemocyte Count (THC) dan histologi organ insang dapat menginformasikan perubahan histologi akibat stressor oleh karena paparan toksik, terutama fenol. Perlakuan sublethal fenol dengan konsentrasi yang berbeda terhadap kepiting bakau (Scylla serata) pada hari ke-1, hari ke-3, hari ke-5 dan hari ke-8 tidak terdapat perbedaan yang signifikan ( $p>0,05$ ) (Lampiran) terhadap rata-rata Total Haemocyte Count (THC). Namun pada hari ke-7 menunjukkan penurunan jumlah THC pada tiap perlakuan bila dibandingkan dengan kontrol (tanpa perlakuan). Perubahan histologi yang terjadi meningkat sebanding dengan konsentrasi fenol yang diperlakukan terhadap kepiting bakau (S. serata). Perubahan histologi yang terjadi adalah kerusakan struktur dari lamela insang (I) dan bagian terluar sinus lamela atau outer lamellar sinuses (ols) yang meliputi infiltrasi hemosit, hiperplasia maupun nekrosis.
\end{abstract}

Kata Kunci : fenol, hepatopankreas, kepiting bakau.

\section{Abstract}

The presence of phenols which exceeds the threshold into the aquatic ecosystem can be a chemical stressors to aquatic organisms, as well as for estuarine ecosystems because of the estuary (estuary) is a regional meeting between fresh water from sea water and river waters contain chemicals, so the potential anthropogenic. Mud crab (Scylla spp.) Has a life cycle that are mostly located in the mangrove ecosystem and commonly used in ecotoxicity studies. Total Haemocyte Count (THC) and gill histology of organs can inform the histological changes caused by due to exposure to toxic stressors, especially phenol. Sublethal treatment with different concentrations of phenol of mangrove crab (S. serata) on day 1 , day 3 , day 5 and day 8 there were no significant differences ( $p>0.05$ ) (Appendix) to the average amount of THC (Total Haemocyte Count). However, on day 7 showed a decrease of THC in each treatment when compared with controls (without treatment). Histological changes that occur increases with the concentration of phenol is treated to mud crab (S. serata). Histological changes that occur is damage to the structure of the gills lamela (I) and the outer portion of an outer lamellar sinus or sinuses lamela (OLS), which includes hemosit infiltration, hyperplasia and necrosis.

Keywords: crab, gill crab, haemocytes, hemocyte infiltration, hyperplasia, necrosis, Scylla serata, THC (Total Haemocyte Count).

\section{PENDAHULUAN}

Fenol dan senyawa fenolik merupakan salah satu xenobiotik yang menjadi salah satu faktor stres lingkungan pada biota yang terpapar dan telah menjadi masalah lingkungan akibat dampak antropogenik pada lingkungan yang ditimbulkannya [1]. Fenol memiliki tingkat bioakumulasi yang cukup tinggi sepanjang rantai makanan, sehingga pencemaran fenol menyaji-kan ancaman tidak

\footnotetext{
* Alamat korespondensi:

Agung Pramana Warih Mahendra

email : agung_pramana@ub.ac.id

Alamat : Fakultas MIPA Universitas Brawijaya, Jl. Veteran, Malang, 65145
}

hanya terhadap lingkungan alam namun juga untuk kesehatan manusia [2]. Disamping itu, fenol dan turunan fenolik termasuk dalam salah satu bahan kimia berbahaya dalam ekosistem perairan yang berpotensi sebagai Endocrine Distrupting Chemical (EDC) dan juga termasuk dalam daftar polutan prioritas Environmental Protection Agency (EPA) oleh karena kehadiran senyawa tersebut pada hewan air dan daerah terrestrial [3].

Fenol dan senyawanya dapat menjadi salah satu bahan pencemar air yang masuk ke alam dan masuk ke dalam perairan melalui limbah cair dari berbagai industri antara lain seperti batubara, manufaktur fenol, farmasi, resin, cat, 
tekstil, kulit, petrokimia, pulpmill [4], limbah fenol juga dapat berasal dari pestisida non spesifik, herbisida, bakterisida dan fungisida [5] maupun berasal dari berbagai proses industri yang digunakan pada gasifikasi batubara dan kilang minyak [4]. Senyawa fenol dapat dikatakan aman bagi lingkungan jika konsentrasinya berkisar antara 0,5-1,0 mg. $\mathrm{L}^{-1}$ sesuai dengan KEP No. 51/MENLH/10/1995. Sedangkan baku mutu yang sesuai dengan ketentuan PP 82/2001, Sungai Kelas III, besarnya konsentrasi fenol maksimum yang diperbolehkan adalah 0,001 mg. $\mathrm{L}^{-1}$ [6]. Hadirnya fenol yang melebihi batas ambang ke dalam ekosistem perairan dapat menjadi stresor kimia bagi organisme akuatik, termasuk juga bagi ekosistem muara oleh karena muara (estuaria) merupakan daerah pertemuan antara air tawar dari perairan sungai dan air laut sehingga berpotensi mengandung bahan kimia antropogenik termasuk bagi kepiting bakau yang hidup di lingkungan muara atau estuaria [7].

Kepiting bakau (Scylla serata) kaya akan rasa, nilai gizi, memiliki ukuran yang lebih besar, harga satuan yang tinggi, serta permintaan yang besar di pasar lokal maupun ekspor. Selain memiliki potensi yang tinggi dari segi ekonomi, kepiting bakau ( $S$. serata) juga memiliki peranan penting dari segi ekologi, terutama di daerah muara yang menjadi habitatnya. Pertumbuhan dan perkembangan kepiting bakau terdiri dari serangkaian siklus hidup atau tahapan yakni larva, remaja, dan dewasa. Terjadinya berbagai perubahan morfologi dan perilaku serta fisiologis dimana dalam serangkaian prosesnya sebagian besar terjadi pada daerah muara [8]. Namun, informasi tentang toksisitas fenol pada organisme perairan estuaria masih terbatas [4] terutama pada spesies kepiting. Oleh karena itu, sangat penting untuk mempelajari risiko yang ditimbulkan oleh polutan pada kepiting bakau [8].

Kepiting bakau merupakan invertebrata yang umum digunakan dalam studi ekotoksisitas polutan dengan berbagai alasan berikut: (1) memiliki distribusi luas di lingkungan muara yang dimanfaatkan sebagai daerah pembibitan untuk pakan, pertumbuhan dan perkembangan (2) bersifat semi pelagik di alam, (3) sensitif terhadap polutan, (4) tersedia sepanjang tahun sehingga meminimalkan kesulitan yang terlibat dalam lokasi dan pengambilan sampel di lapangan, (5) dapat diaklimasi seperti kondisi laboratorium dengan mudah [7].

Teknik hematologi juga merupakan metode umum yang dapat digunakan untuk mengetahui efek sublethal polutan [9]. Selain itu pula, profil protein dari biota berperan dalam menanggapi kimia tertentu yang dapat digunakan sebagai protein penanda terhadap paparan kimia tertentu pada organisme terkena stressor kimia [10]. Oleh karena itu, penelitian ini bertujuan untuk menilai sejauh mana konsentrasi sublethal fenol terhadap Total Haemocyte Count (THC) dan Differential Haemocyte Count (DHC) kepiting bakau (S. serata), sehingga diharapkan informasi ini dapat diintegrasikan sebagai salah satu sistem peringatan dini (early warning) untuk memantau sejauh mana pencemaran fenol dalam perairan dalam upaya untuk menghindari dampak yang lebih jauh pada ekosistem perairan terutama estuaria dan terlebih lagi terhadap populasi manusia.

\section{METODE PENELITIAN \\ Aklimasi}

Sebelum uji toksisitas, kepiting bakau ( $S$. serata) terlebih dahulu diaklimasikan dalam kondisi laboratorium selama 6-8 hari. Kepiting uji yang berukuran panjang $9 \pm 0,5 \mathrm{~cm}$ dan lebar $6 \pm 0,5 \mathrm{~cm}$ dengan berat rata-rata 65-75 gram dipelihara dalam aquarium kaca $40 \times 25 \times 20 \mathrm{~cm}$ dengan volume 10 liter air laut salinitas $25 \%$, kepadatan 10 ekor kepiting per akuarium [11]. Aklimasi tersebut di kondisi laboratorium yang terkendali dengan aerasi konstan [12]. Kepiting bakau diberi pakan dengan moluska dan udang sekali sehari. Pengisian air dilakukan secara rutin setiap 24 jam untuk menghindari residu toksisitas. Suhu, salinitas dan derajat keasaman $(\mathrm{pH})$ dimonitor secara rutin demikian juga dengan oksigen terlarut (DO). Fotoperiodik 12 jam gelap dan 12 jam terang juga diberikan. Kondisi pasang surut disimulasikan di laboratorium dengan meningkatkan dan menurunkan tingkatan air di dalam setiap durasi 12 jam [13].

\section{Uji Toksisitas Fenol}

Setelah aklimasi dengan kondisi laboratorium, uji toksisitas dilakukan untuk menentukan konsentrasi median ( $\mathrm{LC}_{50}$ ) fenol pada kepiting bakau ( $S$. serata). Penentuan $\mathrm{LC}_{50}$ dilakukan untuk mendapatkan nilai ambang batas konsentrasi median toksisitas fenol pada kepiting bakau. Masing-masing kepiting bakau dibagi menjadi beberapa kelompok dan setiap kelompok berisi 10 kepiting dalam kaca akuarium berisi air laut salinitas 22\%o, dalam tiga kali replikasi. Larutan stok, dibuat konsentrasi fenol yang diinginkan untuk menentukan toksisitas 
kepiting bakau. Selama uji toksisitas berlangsung, tidak dilakukan pemberian pakan [11]. Kepiting secara rutin diperiksa mortalitas-nya. Kepiting yang mengalami kematian langsung dibuang untuk menghindari toksisitas tambahan dan kualitas air yang jelek [14]. Data mortalitas diolah dengan regresi linier $(\mathrm{Y}=\mathrm{a}+\mathrm{bx})$ untuk mendapatkan nilai $\mathrm{LC}_{50}$ (96 jam). Selama perlakuan percobaan, wadah uji ditutupi oleh tutup untuk mencegah pengeringan lewat atmosfer [14].

\section{Pengamatan Hemosit THC}

Hemolymph kepiting bakau yang dikumpulkan secara aseptik dari membran arthrodial proksimal pada dasar kaki jalan kedua kanan dari kepiting menggunakan jarum suntik 26 gauge ukuran $1 \mathrm{ml}$ dengan menggunakan sodium sitrat $10 \%$ sebagai antikoagulan dengan perbandingan 1:1 (100 $\mu$ l hemosit : $100 \mu l$ anti koagulan). Kemudian, hemosit digolongkan menggunakan kriteria sederhana dengan melihat ada atau tidak adanya butiran sitoplas dan sedikit atau banyaknya granula. Kemudian dihitung jumlah total dan jumlah diferensial hemosit [15]. Hemolymph diambil sebanyak $100 \mu$ per individu kepiting di pindahkan kedalam tabung eppendorf yang berisi $900 \mu \mathrm{l}$ Tripan blue stain solution. Tetesan pertama hemolimph pada syringe dibuang, selanjutnya hemolimph diteteskan pada haemocytometer dan dihitung jumlah selnya per $\mathrm{ml}$ dibawah mikroskop dengan pembesaran 40 kali. Total hemosit dihitung dengan menggunakan formulasi [16].

\section{HASIL DAN PEMBAHASAN}

Uji Toksisitas Akut LC $_{50}$ (96 Jam) Bahan Toksik Fenol Terhadap Kepiting Bakau (S. serata)

Uji toksisitas akut LC $_{50}$ (96 jam) fenol terhadap kepiting bakau (S. serata) dilakukan untuk menentukan lethal concentration 50\% digunakan lima perlakuan konsentrasi yang berbeda yakni perlakuan A (16 mg. $\left.\mathrm{L}^{-1}\right), \mathrm{B}$ (32 $\left.\mathrm{mg} \cdot \mathrm{L}^{-1}\right), \mathrm{C}\left(64 \mathrm{mg} \cdot \mathrm{L}^{-1}\right), \mathrm{D}\left(128 \mathrm{mg} \cdot \mathrm{L}^{-1}\right)$ dan kontrol (tanpa perlakuan). Pada uji toksisitas akut tersebut, persentase mortalitas kepiting bakau (S. serata) tertinggi adalah pada perlakuan D (100\%) kemudian diikuti perlakuan C (70\%), B (50\%), A (40\%), dan K (0\%). Berdasarkan perhitungan dengan analisis probit maka dapat diketahui nilai LC $_{50}$ (96 jam) fenol terhadap kepiting bakau (S. serata) adalah $26 \mathrm{mg} \cdot \mathrm{L}^{-1}$. Data perhitungan penentuan konsentrasi $\mathrm{LC}_{50}$ (96 jam) fenol terhadap kepiting bakau ( $S$. serata) berdasarkan analisis probit ditunjukkan pada Tabel 1.

Tabel 1. Perhitungan penentuan konsentrasi $\mathrm{LC}_{50}(96$ jam) fenol terhadap kepiting bakau (S. Serata) berdasarkan analisis probit

\begin{tabular}{cccc}
\hline $\begin{array}{c}\text { Konsentrasi } \\
(\mathrm{ppm})\end{array}$ & $\begin{array}{c}\text { Log } \\
\text { Konsentrasi }\end{array}$ & $\begin{array}{c}\text { Persen } \\
\text { Kematian (\%) }\end{array}$ & $\begin{array}{c}\text { Nilai } \\
\text { probit }\end{array}$ \\
\hline 16 & 1,2041 & $40 \%$ & 4,75 \\
32 & 1,5051 & $50 \%$ & 5,00 \\
64 & 1,8062 & $70 \%$ & 5,52 \\
128 & 2,1072 & $100 \%$ & 8,09 \\
\hline
\end{tabular}

Persamaan regresi yang diperoleh dari data diatas adalah $Y=3,5012 X+0,0433(r=0,8871)$. Nilai $\mathrm{LC}_{50}$ (96 jam) diperoleh dengan cara memasukan nilai probit 5,00 (\% kematian 50\%) sebagai variabel $Y$ kedalam persamaan regresi tersebut, sehingga didapatkan median konsentrasi letal $50 \% \quad\left(\right.$ LC $\left._{50}\right)$ selama 96 jam fenol terhadap kepiting bakau (S. serata) sebesar $26 \mathrm{mg} \cdot \mathrm{L}^{-1}$.

\section{Uji Toksisitas Sublethal Fenol Terhadap Kepiting Bakau (S. serata)}

Konsentrasi perlakuan yang digunakan untuk uji toksisitas sublethal tersebut mengacu pada nilai $\mathrm{LC}_{50}-96$ jam yang telah didapatkan dari uji toksisitas akut. Selama penelitian berlangsung pergantian media uji sehari sekali. Pemberian pakan kepiting bakau (S. serata) dilakukan 2 kali sehari, yaitu pagi dan sore. Kepadatan kepiting uji adalah lima ekor kepiting bakau (S. serata) per unit percobaan, yang diisi 5 liter air payau dengan salinitas sebesar 22 ppt. Parameter kualitas air yang diamati adalah, oksigen terlarut (DO), suhu dan derajat keasaman $(\mathrm{pH})$ yang diamati setiap hari. Perlakuan pada uji toksisitas sublethal adalah berdasarkan nilai sublethal atau setengah nilai $\mathrm{LC}_{50}-96$ jam ke seri tingkatan konsentrasi yang lebih rendah. Konsentrasi fenol yang digunakan untuk uji toksisitas sublethal selama 7 hari adalah $1 / 16,1 / 4$ dan $1 / 2$ dari LC $_{50^{-}}$ 96 jam. Jadi konsentrasi perlakuan pada uji toksisitas sublethal adalah sebagai berikut: kontrol (tanpa perlakuan), perlakuan A $(1,62$ mg. $\left.\mathrm{L}^{-1}\right)$, perlakuan $B\left(6,5 \mathrm{mg} \cdot \mathrm{L}^{-1}\right)$, perlakuan C (13 $\left.\mathrm{mg} \cdot \mathrm{L}^{-1}\right)$. Pengamatan yang dilakukan pada uji toksisitas sublethal adalah perhitungan total hemosit atau Total Haemocyte Count (THC) dan histologi organ insang kepiting bakau (S. serata).

\section{Total Haemocyte Count (THC)}

Hasil perhitungan Total Haemocyte Count (THC) kepiting bakau (S. serata) selama uji sublethal fenol ditampilkan pada tabel berikut. 
Tabel 2. Hasil perhitungan Total Haemocyte Count (THC) kepiting bakau (S. serata) selama uji sublethal fenol

\begin{tabular}{cccccc}
\hline \multirow{2}{*}{ Perlakuan } & \multicolumn{5}{c}{ Rerata THC } \\
\cline { 2 - 6 } & Hari ke-1 & Hari ke-2 & Hari ke-3 & Hari ke-4 & Hari ke-5 \\
\hline K & $22,42 \pm 1,13$ & $22,92 \pm 0,80$ & $22,92 \pm 1,26$ & $23,08 \pm 1,61$ & $22,45 \pm 0,82$ \\
A & $20,08 \pm 0,95$ & $23,75 \pm 0,66$ & $22,00 \pm 0,66$ & $19,83 \pm 1,23$ & $18,5 \pm 2,65$ \\
B & $21,00 \pm 1,64$ & $25,33 \pm 0,76$ & $21,00 \pm 2,75$ & $19,08 \pm 2,84$ & $19,42 \pm 3,22$ \\
C & $20,42 \pm 0,80$ & $24,42 \pm 1,67$ & $21,75 \pm 2,88$ & $16,25 \pm 2,05$ & $15,92 \pm 2,16$ \\
\hline
\end{tabular}

Rata-rata jumlah THC kepiting bakau ( $S$. serata) pada kontrol (tanpa perlakuan) hari ke-1 sebesar $22,42 \times 10^{6}$ sel. $\mathrm{mL}^{-1}$ dan pada hari ke-3 memiliki rata-rata jumlah THC sebesar $22,9 \times 10^{6}$ sel. $\mathrm{mL}^{-1}$ yang juga sama dengan jumlah THC pada hari ke-5 perlakuan. Namun kemudian mengalami kenaikan jumlah THC menjadi $23 \times 10^{6}$ sel. $\mathrm{mL}^{-1}$ pada hari ke-7 perlakuan. Pemberian konsentrasi fenol pada perlakuan A (1,62 ppm) jumlah THC pada hari ke-1 terhitung sebesar $20,08 \times 10^{6}$ sel. $\mathrm{mL}^{-1}$, kemudian mengalami kenaikan jumlah THC pada hari ke-3 menjadi $23,75 \times 10^{6}$ sel. $\mathrm{mL}^{-1}$, namun pada hari ke-7 perlakuan jumlah THC mengalami penurunan jumlah THC menjadi $19,83 \times 10^{6}$ sel.mL ${ }^{-1}$. Sedangkan pada pemaparan konsentrasi sublethal fenol yang lebih tinggi, yakni perlakuan B (6,5 ppm) menunjukkan jumlah THC pada hari1 perlakuan sebesar $21 \times 10^{6}$ sel. $\mathrm{mL}^{-1}$, kemudian mengalami peningkatan pada hari ke-3 dengan jumlah THC sebesar $25,33 \times 10^{6}$ sel. $\mathrm{mL}^{-1}$.

Sedangkan pada hari ke-5 total hemosit kepiting bakau (S. serata) pada perlakuan B $(6,5$ $\mathrm{ppm})$ menjadi $21 \times 10^{6}$ sel. $\mathrm{mL}^{-1}$ yang berarti mengalami penurunan bila dibandingkan dengan jumlah THC pada perlakuan hari ke-3 dan pada hari ke-7 jumlah THC mengalami penurunan menjadi $19 \times 10^{6}$ sel. $\mathrm{mL}^{-1}$. Sedangkan pada pemberian konsentrasi fenol tertinggi yakni perlakuan C (13 ppm) jumlah THC pada hari ke-3 mengalami peningkatan dibandingkan dengan hari ke-1. Namun sebaliknya, pada hari ke-5 mengalami penurunan jumlah THC menjadi $21 \times 10^{6}$ sel. $\mathrm{mL}^{-1}$, kemudian menjadi semakin turun pada hari ke-7 perlakuan yakni menjadi $16,25 \times 10^{6}$ sel. $\mathrm{mL}^{-1}$.

Berdasarkan hasil analisa ragam (ANOVA) dari pengolahan data hasil penelitian dengan bantuan SPSS 17, menunjukkan bahwa yang berpengaruh nyata hanya perlakuan konsentrasi sublethal fenol pada hari ke-7, jadi yang diuji lanjut hanya perlakuan pada hari ke-7. Sedangkan perlakuan sublethal fenol dengan konsentrasi yang berbeda yang diperlakukan pada kepiting bakau ( $S$. serata) pada hari ke-1, hari ke-3, hari ke-5 dan hari ke-8 tidak terdapat perbedaan yang signifikan $(p>0,05)$ (Lampiran) terhadap rata-rata jumlah THC. Namun pada perlakuan A (1,62 mg. L $^{-}$ $\left.{ }^{1}\right), B\left(6,5 \mathrm{mg} \cdot \mathrm{L}^{-}{ }^{1}\right)$ dan C (13 mg. $\left.\mathrm{L}^{-1}\right)$ pada hari ke-3 perlakuan menunjukkan peningkatan jumlah THC bila dibandingkan dengan kontrol (tanpa perlakuan). Grafik THC pada tiap konsentrasi perlakuan selama uji sublethal fenol ditunjukkan pada gambar berikut.

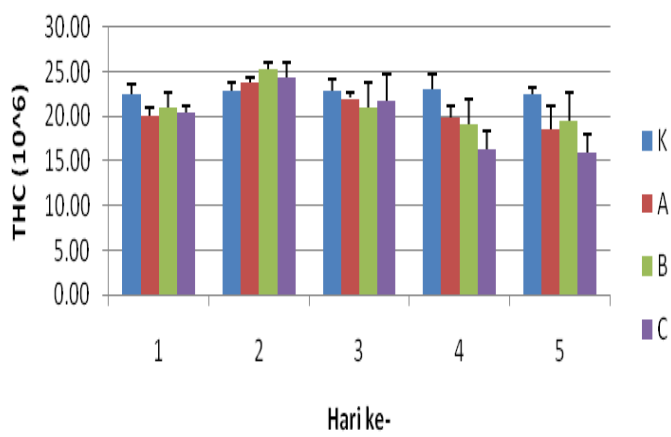

Gambar 1. THC (Total Haemocyte Count) kepiting bakau (S. serata) pada awal hingga akhir perlakuan Uji Sublethal Fenol

\section{Histologi Insang Kepiting Bakau (S. serata)}

Berdasarkan hasil pengamatan, perlakuan $A$ (1,62 mg. $\left.\mathrm{L}^{-1}\right)$ terlihat bagian lamela insang tampak sudah mulai mengalami kerusakan epitel. Selain itu, haemocoels ( $\mathrm{Hc}$ ) menjadi lebih besar dengan lebih banyak hemosit dan tampak tidak teratur saat diperbesar, makin jelas terlihat pada perlakuan konsentrasi sublethal fenol perlakuan B $\left(6,5 \mathrm{mg} \cdot \mathrm{L}^{-1}\right)$ (Gambar 2b) dan C (13 mg. $\mathrm{L}^{-1}$ ) (Gambar 2c). Hal tersebut dicirikan oleh bentuk outer lamela sinus (ols) yang nampak tidak beraturan dan pada beberapa insang cabang terjadi fusi lamela serta adanya infiltrasi hemosit. 


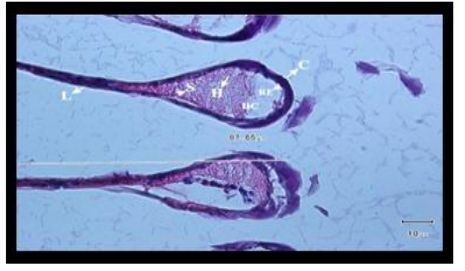

(A)

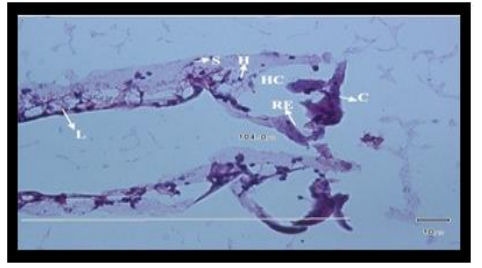

(B)

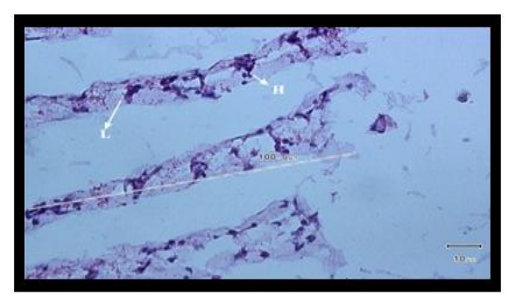

(C)

Gambar 2. Lamela insang yang menunjukkan lesi epitel dan infiltrasi hemosit pada masing-masing perlakuan konsentrasi sublethal fenol (H: hemocyte; HC: haemocoel; L: lamella; C: cuticule)

Sel hemosit merupakan sel-sel darah yang beredar pada invertebrata yang merupakan efektor imun utama yang melakukan fungsi imunologi beragam termasuk fagositosis, generasi molekul sitotoksik dibawah paparan racun dan juga termasuk pemeliharaan homeostasis serta bertanggung jawab dalam berbagai mekanisme perlindungan [11]. Jumlah THC diyakini mempengaruhi kemampuan organisme untuk bereaksi melawan bahan asing [17] dan berbagai respon terhadap infeksi, perubahan lingkungan pada sebagian besar crustacea [18]. Namun pada spesies dekapoda krustasea, jumlah hemosit yang berkaitan dengan pertahanan seluler bervariasi diantara spesies satu dengan yang lainnya [19].

Kelimpahan hemosit yang beredar pada dasarnya dipengaruhi oleh beberapa faktor diantaranya adalah jenis kelamin, molting, status reproduksi dan nutrisi, ukuran, seks, dan berat badan. Selain itu pula, juga karena faktor musim. Sebagai contoh yakni spesies dari kelas krustasea lainnya, seperti udang galah ( $M$. rosenbergii) menunjukkan jumlah THC tertinggi dan terendah di musim gugur dan musim dingin, masingmasing. Namun tidak terdapat perbedaan yang signifikan antara jantan maupun betina [20]. Sedangkan faktor - faktor ektrinsik seperti suhu, salinitas dan oksigen terlarut juga dilaporkan dapat mempengaruhi jumlah THC (Total Haemocyte Count) beberapa spesies dekapoda krustasea [20, 21]. Hasil studi pada udang Penaeus stylirostris pada suhu rendah sebesar $18^{\circ} \mathrm{C}$ terjadi penurunan yang signifikan terhadap jumlah THC sebesar $40 \%$ dibandingkan dengan udang yang dipelihara pada suhu $27^{\circ} \mathrm{C}$ [22].

Selain itu, faktor hipoksia juga dapat menjadi penyebab penurunan jumlah THC. Faktor hipoksia secara signifikan juga dapat menurunkan jumlah THC, seperti pada spesies udang $P$. Stylirostris. Konsisi hipoksia tersebut menyebabkan menjadi stres dan rentan terhadap infeksi Vibrio alginolyticus [21]. Jumlah THC udang putih terinfeksi Taura Syndrom Virus (TSV) menurun 79\%. Jumlah THC pada spesies udang windu Penaeus monodon dan Penaeus japonicus yang terinfeksi White Spot Syndrom Virus (WSSV) juga menunjukkan penurunan secara signifikan [23]. Sedangkan peningkatan suhu dari $10-20^{\circ} \mathrm{C}$ dan $18-32^{\circ} \mathrm{C}$ juga memicu peningkatan jumlah THC dari Carcinus maenas [24]. Sedangkan untuk faktor salinitas, pada spesies udang Penaeus paulensis Brasil yang dipelihara pada salinitas $34 \%$ memiliki jumlah THC secara signifikan lebih tinggi (20\% lebih) dari udang yang dipelihara pada $13-22 \%$ [22]. Sedangkan penurunan jumlah THC oleh karena pengaruh oksigen terlarut (DO) pada udang $P$. stylirostris dengan pemeliharaan pada oksigen terlarut terendah sebesar $1 \mathrm{mg} \cdot \mathrm{L}^{-1}$ selama 24 jam [21].

Selain jumlah total hemosit (THC), pengamatan histologi juga merupakan hal penting untuk melihat sejauh mana pengaruh stressor bahan toksik fenol terhadap kepiting bakau (S. serata). Insang merupakan organ vital yang memainkan peran penting dalam transportasi pernapasan gas dan regulasi keseimbangan osmotik dan ion pada organisme akuatik. termasuk juga pada spesies kepiting 
bakau (S. serata). Osmoregulasi merupakan salah satu hal yang paling penting dalam menunjang fungsi regulasi hewan akuatik, terutama pada kelas krustasea [25]. Seperti halnya pada spesies kepiting biru $C$. sapidus. kepiting ini dapat mempertahankan osmolaritas hemolymph meskipun berada dalam kondisi salinitas tinggi dan rendah dengan aktif memompa ion melalui insang [26] terutama bagian posterior insang merupakan situs utama untuk transpor ion dan menunjukkan aktivitas enzim yang lebih tinggi serta berperan dalam mekanisme transportasi ion dan memiliki lebih kaya akan mitokondria pada anterior sel-sel dari insang yang dianggap sebagai situs utama pernapasan, menunjukkan gerakan pasif $\mathrm{Na}^{+}$[27].

Paparan zat beracun termasuk fenol dapat merusak jaringan insang, sehingga hal ini dapat mengurangi konsumsi oksigen dan mengganggu fungsi osmoregulasi organisme air. Keadaan patologis insang yang semakin parah akibat paparan zat beracun dapat menyebabkan gangguan pernapasan dan akhirnya menyebabkan kematian organisme tersebut [28]. Pemaparan logam berat merkuri klorida udang air tawar Macrobrachium menunjukkan pembesaran lamela insang dengan peningkatan hemosit [29].

\section{DAFTAR PUSTAKA}

[1] Abdel-Hameid N.A.H. 2007. Physiological and Histopathological Alterations Induced by Phenol Exposure in Oreochromis aureus Juveniles. Turkish Journal of Fisheries and Aquatic Sciences. 7: 131-138.

[2] Hori, T.S.F., Avilez, I.M., Inoue, L.K. dan Moraes, G. 2006. Metabolical changes induced by chronic phenol exposure in matrinxã Brycon cephalus (teleostei: characidae) juveniles. Comp. Biochem. Physiol., 143(1): 67-72.

[3] Llompart M., Lourido M., Landin P., GarciaJares C., dan Celo R. 2002. Optimization of a derivatization-solid-phase microextraction method for the analysis of thirty phenolic pollutants in water samples. J. Chromatogr. 963: 137-148.

[4] Saha N.C., Bhunia F., dan Kaviraj A. 1999. Toxicity of phenol to fish and aquatic ecosystems. Bulletin of Environmental Contamination and Toxicology. 63: 195.202

[5] Gupta S., Dalela R.C., dan Saxena P.K. 1983. Effect of phenolic compounds on in vivo activity of transaminases in certain tissues of the fish of the fish Notopterus notopterus. Environ. Res. 32: 8-13.

[6] Herawati N., Purwanto, dan Hadiyarto A. 2007. Analisis risiko lingkungan aliran Lumpur Lapindo ke badan air (studi kasus Sungai Porong dan Sungai Aloo Kabupaten Sidoarjo). Program Studi Magister Ilmu Lingkungan Pasca Sarjana. Universitas Diponegoro. Semarang.

[7] Vijayavel K., Gopalakrishnan S., Thiagarajan R., dan Thilagam H. 2008. Immuno-toxic Effects of Nickel in the Mud Crab Scylla serrata. Fish and Shellfish Immunology. 26 (1): 133-139.

[8] Vijayavel K. dan Balasubramanian M.P. 2005. Fluctuations of biochemical constituents and marker enzymes as a consequence of Naphthalene Toxicity in an Estuarine Edible Crab Scylla serrata. Ecotoxicology Environmental Safety. 63: 141-147.

[9] Larsson U., Elmgren R., dan Wulff F. 1985. Eutrophication and the Baltic Sea: Causes and consequences. Ambio. 14: 10-14.

[10] Vom Saal F.S. dan Welshons W.V. 2006. Large effects from small exposures II. The importance of positive controls in low-dose research on Bisphenol $A$. Environmental Research. 100: 50-76.

[11] Vijayavel K., Fung D.Y.C., dan Fujioka R.S. 2009. Modification of Fung Double Tube and CP anaselect oxyplate methods to improve their performance in enumerating Clostridium perfringens from sewage and environmental waters. J. Rapid Methods Autom. Microbiol. 17: 535-549.

[12] Saha S., Ray M., dan Ray S. 2010. Screening of phagocytosis and intrahemocytotoxicity in arsenic exposed crab as innate immune response. Asian Journal Experimental Biological Sciences. 1: 47-54.

[13] Saha S., Ray M., dan Ray S. 2010. Shift in cytoarchitecture of immunocytes of mudcrab exposed to arsenic. International Journal of Applied Biology and Pharmaceutical Technology. 1 (2): 234-246.

[14] Saha P., Selvan V.T., Mondal S.K., Mazumder U.K., dan Gupta M. 2008. Antidiabetic and antioxidant activity of Methanol extract of Ipomoea reptans poir aerial parts in Streptozotocin induced diabetic rats. Pharmacologyonline. 1: 409421.

[15] Yildiz H.Y. dan Atar H.H. 2002. Haemocyte classification and differential counts in the 
freshwater Crab, Potamon fluviatilis. Turkish Journal of Veterinary and Animal Sciences. 26: 403-406.

[16] Wootton E.C., Dyrynda E.A., san Ratcliffe N.A. 2003. Bivalve immunity: comparisons between the marine mussel (Mytilus edulis), the edible cockle (Cerastoderma edule) and the razor-shell (Ensis siliqua). Fish and Shellfish Immunology. 15(3): 195-210.

[17] Persson M., Vey A., dan Söderhäll K. 1987. Encapsulation of foreign particles in vitro by separated blood cells from crayfish, Astacus leptodactylus. Cell Tissue Res. 247: 409-415.

[18] Tsing, A., Arcier, J. M. dan Brehélin, M. (1989). Haemocytes of penaeid and palaemonid shrimps: Morphology, cytochemistry and hemograms. J. Invert. Pathol. 53: 64-77.

[19] Hose J. E., Martin G.G. dan Alison S.G. 1990. A decapod hemocyte classification scheme integrating morphology, cytochemistry, and function. The Biolological Bulletin. 178: 3345.

[20] Cheng W. dan ChenJ.C. 2001. Effect of intrinsic and extrinsic factors on the hemocyte profile of the prawn, Macrobarchium rosenbergii. Fish Shelfish Immunol. 11: 53-63.

[21] Le Moullac G., Soyez C., Saulnier D., Ansquer D., Avarre J.C., dan Levy P. 1998. Effect of hypoxia stress on the immune response and the resistance to vibriosis of the shrimp Penaeus stylirostris. Fish Shellfish Immunol. 8: 621-629.

[22] Le Moullac G. dan Haffner P. 2000. Environmental factors affecting immune response in crustacean. Aquaculture. 191: 121-131.

[23] Le Moullac G.L., Le Groumellec ML., Ansquer D., Froissard S., Levy P., dan Aquacop. 1997. Haematological and phenoloxidase activity changes in the shrimp Penaeus stylirostris in relation with the molt cycle: protection against vibriosis. Fish Shellfish Immunol. 7: 227-234.

[24] Truscott R. dan White K.N. 1990. The influence of metal and temperatures stress on the immune system of crabs. Func. Ecol. 4: 455-461.

[25] Chang E.S. 2005. Stressed-out lobsters: crustacean hyperglycemic hormone and stress proteins. Integr. Comp. Biol. 45: 4350.

[26] Towle D.W., Palmer G.E., dan Harris lii J.L. 1996. Role of gill $\mathrm{Na}^{++} \mathrm{K}^{++}$dependent ATPase in acclimation of blue crabs (Callinectes sapidus) to low salinity. J. Exp. Zool. 196: 315-322.

[27] Henry R.P. 2005. Critical salinity, sensitivity, and commitment of salinity-mediated carbonic anhydrase induction in the gills of two euryhaline species of decapods crustaceans. J. Exp. Zool. 303A: 45-56.

[28] Rodriguez J. dan Moullac G.L. 2000. State of the art of immunological tools and health control of Penaeid Shrimp. Aquaculture. 191: 109-119.

[29] Victor B., Narayanan M., dan Nelson D. 1990. Gill pathology and hemocyte response in mercury exposed Macrobrachium idea (Heller). J. Environ. Biol. 11: 61-65. 